\title{
16 ASPECTS ON INFORMATION SYSTEMS CURRICULUM: A Study Program in Business Informatics
}

\author{
Markus Helfert \\ Howard Duncan \\ Dublin City University \\ Dublin, Ireland
}

\begin{abstract}
Despite the variety of traditional study programs related to Information Systems and the formation of combinations between computing, business, and management studies, at present universities seem to be not well prepared to equip graduates with the valuable knowledge and skills required for organizational transformation. Consequently, traditional study programs and career paths for Information Systems graduates might have to be revised and new programs established. Addressing the need for an innovative and crossdisciplinary study model to equip graduates with transformation skills, in 2003 we started to develop a master's program in Business Informatics. This paper outlines the core elements of this program and explores how we equip students with capabilities required for transformation processes. We provide experiences from the interdisciplinary accreditation process of the program and outline our future plans.
\end{abstract}

Keywords Transformation, business informatics, curriculum development, change management

\section{INTRODUCTION}

Driven by technological innovations, organizations periodically face radical and dramatic transformation, in which well-established structures, successful for decades, have started to change rapidly. Consequently organizations are frequently required to realign their structures. The need for transformation has accelerated the introduction of new methods, processes, and structures (Evans and Wurster 1999). However, many organizations fail to design technological solutions that provide a sustainable compe-

Please use the following format when citing this chapter:

Helfert, Markus, Duncan, Howard, 2006, in International Federation for Information Processing (IFIP), Volume 206, The Transfer and Diffusion of Information Technology for Organizational Resilience, eds. B. Donnellan, Larsen T., Levine L., DeGross J. (Boston: Springer), pp. 229-237. 
titive advantage. In this context, organizational resilience is seen as one of the core capabilities for organizations and individuals to absorb strain and recover from untoward events through continuous reconstruction (Mallak 1998). Using Holling's (1973, p. 17) definition of resilience - "the capacity of a system to absorb and utilize or even benefit from perturbations and changes that attain it, and so to persist without a qualitative change in the system's structure" - the resilient organization designs and implements the structures effectively, as positive adaptive behaviors that are quickly matched to the immediate situations (Mallak 1998). However, individuals often face these situations without adequate training or preparation.

In general, information system graduates should be equipped with the capability to analyze organizational processes and solve business problems. Considering the difficulties noted above, they also require capabilities to initiate and lead transformation as well as understanding the wider social, economic, and cultural implications of proposed transformations. The interdisciplinary character will increase as claims that IT is no longer a source of strategic advantage have generated a growing concern over the loss of pure technology-oriented jobs (Carr 2003) and increased the demand for businessoriented IT jobs (Benamati and Mahanney 2004). It is expected that demand will increase for integration, enterprise architecture, information management, and business process management. The demand for graduates capable of coordinating complex information and supply chain networks and project mangers coordinating global IT projects is expected to increase. Young professionals may need to understand how to manage project teams and lead change, especially in geographically and ethnically diverse teams.

However, despite the fact that computing departments are forming valuable relationships with business and management studies, at present universities are often challenged to equip graduates with the required transformation skills. A recent exploratory study by Helfert and Duncan (2005) illustrates the variety of traditional Information Systems related study programs. Universities offer a variety of courses for many years. Nonetheless, the dynamics and rapid changes in recent years demand education programs that equip graduates with the capability to manage transformation. This is the core field of interest in this article, in which we provide some aspects on information system curriculum and outline a Master's program that is intended to equip graduates with the capabilities for organizational transformation.

As a thematic framework, we use the concept of "business informatics," which seems to be suitable to offer core capabilities related to managing IT-related transformations. Section three provides a summary of the experience made during the accreditation process and describes some characteristics of the program. We conclude our work with further directions and suggestions.

\section{BUSINESS INFORMATICS}

Over the past few decades, Business Informatics has matured as a stream of research and study within the field of Information Systems, with a growing number of universities offering study programs in Business Informatics. In contrast to informatics, which primarily concerns the technology of information and communication systems, 
and business, which focuses on management functions, Business Informatics centers on business information systems as socio-technical systems comprising both machines and humans (e.g., Ferstl and Sinz 2001; Gesellschaft für Informatik 2003; Heinrich 2001; Mertens 1998; Scheer 1998; Wissenschaftliche Kommission der Wirtschaftsinformatik 1994).

The success of the subject derives from a coherent methodological approach. Similar to the business engineering approach (Winter 2002), business informatics requires a holistic and interdisciplinary view of transformation, which not only considers technical and business aspects, but also cultural, political, and social issues that are crucial for successful transformation. Business informaticians must be capable of applying technical and managerial competence to envision, design, communicate, lead, and implement transformation projects. Guided by engineering principles, the transformation process is implemented through a methodological approach. Indeed the holistic and methodological approach based on engineering principles is central to business informatics, which can be summarized as a socio-technological and business oriented subject with engineering penetration (Disterer et al. 2003). Business informatics centers on information systems architectures and takes an active role in aligning business strategy, business processes, and information technology.

In order to construct a basic framework for business informatics study programs in our previous work (Helfert and Duncan 2005), we synthesized the MSIS 2000/IS 2002 model curriculum framework (Gorgone et al. 2000, 2002) and the recommendation for business informatics at universities (Gesellschaft für Informatik 2003). Our final framework is presented in the appendices. The structure follows basically the proposed curriculum building blocks in the MSIS curriculum. However, in order to accommodate the particular subjects related to business informatics, we added subject blocks of mathematics and logic, structural science, legislation, economics, and business engineering. We also included often-taught business subjects like logistics, procurement, and supply chain management. The list of career electives and domain-specific subjects presented here illustrates just some of the possible topics.

\section{A MASTER OF SCIENCE IN BUSINESS INFORMATICS}

\subsection{Diversity of Information Systems}

The curriculum for a Master's program in Business Informatics was developed over the last 2 to years, with the valuable support of an international accreditation board. The board included four international experts in the field of Business Informatics from Ireland, UK, and Austria. Representing the interdisciplinary character of the program, we aimed to include members from different backgrounds representing a thematically wellbalanced accreditation board. Members of the board presented particular expertise in

- knowledge and data engineering and process modeling

- strategic information systems

- information systems management

- practical approaches in the banking sector 
Table 1. Framework for Information Systems' Viewpoints

\begin{tabular}{|c|c|c|c|c|}
\hline & \multicolumn{3}{|c|}{ Perspective } \\
\hline & & $\begin{array}{l}\text { Informatics/ } \\
\text { Computing }\end{array}$ & $\begin{array}{l}\text { Information } \\
\text { Systems }\end{array}$ & $\begin{array}{l}\text { Business and } \\
\text { Management }\end{array}$ \\
\hline \multirow{2}{*}{ 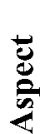 } & $\begin{array}{l}\text { Subjects/Topics to be } \\
\text { included }\end{array}$ & & & \\
\hline & Teaching mode & & & \\
\hline
\end{tabular}

Between the first proposal for the program in 2004 and the final recommendation for accreditation in May 2005, the accreditation board met and discussed the curriculum three times. During the meetings the diversity of particular expertise was reflected within the discussions and recommendations, which led to changes for the program. The diversity of different viewpoints made it difficult to maintain the characteristics of business informatics throughout the program. It seems the curriculum should include many related subjects ranging from business and information system strategy to mathematics, statistics and programming.

The discussions indicated that the controversy is often due to two complementary but fundamentally different streams in Information Systems, with on the one hand a technology, engineering, and method oriented perspective and, on the other, a businessand management-orientated focus. A different emphasis in Information Systems related degrees was observed, with an emphasis on management aspects on the one hand, and the business informatics and information systems engineering perspective on the other. In order to structure the different backgrounds and viewpoints we propose a framework that is illustrated in Table 1. This framework will be used in our further research to structure the diversity of Information Systems degrees.

\subsection{Program Layout}

The central focus of the proposed curriculum for business informatics is to qualify individuals to lead IS-related transformations, enabling them to apply technological solutions and develop information system architectures to solve business problems of organizations. With this goal in mind, the curriculum focuses on an engineering perspective and the integration of cultural studies. The program is intended for students who have achieved a primary degree in Computing, Computer Science, Software Engineering, or a comparable discipline. The program is designed to be completed in one calendar year of full-time study and consists of two taught semesters followed by a practical project.

\subsubsection{Curriculum Structure}

The curriculum emphasizes engineering principles and includes a module on structural science, which encompasses management science, data engineering, and data mining. It also has a strong modeling component, and includes modules on IS architec- 
Table 2. Curriculum Overview

\begin{tabular}{|c|c|c|}
\hline Semester 1 & $\begin{array}{l}\text { - Research Skills/Seminar } \\
\text { Topics } \\
\text { - Information System } \\
\text { Architecture } \\
\text { - Structural Science }\end{array}$ & $\begin{array}{l}\text { - Business Process Management } \\
\text { - Strategic Management of } \\
\text { Information Technology } \\
\text { - Business Studies }\end{array}$ \\
\hline Semester 2 & $\begin{array}{l}\text { - Supply Chain Management } \\
\text { - Managing and Working in an } \\
\text { Intercultural Environment } \\
\text { - Managing Change }\end{array}$ & $\begin{array}{l}\text { - Sectoral applications of } \\
\text { Information Systems } \\
\text { - Regulation in Information } \\
\text { Systems } \\
\text { - Project Management }\end{array}$ \\
\hline Summer & \multicolumn{2}{|l|}{ - Dissertation/Practicum } \\
\hline
\end{tabular}

ture and business process management. The integrative perspective is provided by the supply chain management module. The program also covers the more traditional Information Systems disciplines such as strategic management of information technology. An overview of the general program structure is provided in Table 2. Three complementary strands can be identified in the program, which can be related to our business informatics framework: business and consulting skills, information technology/ information systems in business, and informatics in action. These are illustrated in the appendix.

\subsubsection{Transferable Skills}

In addition to the emphasis on engineering principles and core subjects of business informatics, the study program also supports the building of capabilities for managing transformations by aiming to expand transferable skills. In essence, transferable skills are those skills which, having been learned in one context, can then be applied in another. A summary of transferable skills by module is provided in the appendix. Typically these skills are based on modern teaching, learning, and assessment methods, that include

- guided independent study and activity, with specialist input when appropriate

- recent or current case studies

- essay and report writing

- collaborative group work and discussions

- presentation of findings to the group as a whole

\subsubsection{Practicum}

In the final semester, from May to August, students work on a practicum or major project of a practical nature. The general objective of the practicum is to allow students to draw on the theoretical knowledge gained over the taught element and to apply it in a practical setting in a European environment. The practicum gives students the oppor- 
tunity to demonstrate their ability to analyze problems in the field of Business Informatics and draw conclusions according to scientific methods within a given time frame.

\section{CONCLUSION AND FUTURE DIRECTIONS}

This paper presented aspects on an Information Systems related curriculum and summarized some experiences gained during the accreditation process. The final curriculum as outlined above comprises a balanced and interdisciplinary structure, which centered on engineering principles and focuses on transformation, models, and methods. The engineering penetration throughout the program is seen as one important characteristic, which differentiates this program from management oriented information systems degrees. Therefore, the business informatics approach appears to us not only to be innovative with regard to its interdisciplinary character, but moreover the engineering perspective and the integration of cultural studies and practical experiences in an international setting equip graduates with required transformation capabilities. The program will be launched in September 2006, and further evaluation and adjustments to the curriculum might be required. In our further research we intend to analyze the differences to other information system programs. Also, an evaluation of the gained capabilities in the form of transformation skills would be interesting.

\section{References}

Benamati, S., and Mahaney, R. "The Future Job Market for Information System Graduates," in Proceedings of the $10^{\text {th }}$ Americas Conference on Information Systems, New York, 2004, pp. 2925-2928.

Carr, N. G. "IT Doesn't Matter," Harvard Business Review (85:5), 2003, pp. 41-49.

Disterer, G., Fels, F., and Hausotter, A.(eds). Taschenbuch der Wirtschaftsinformatik ( $2^{\text {nd }}$ ed.), Munich: Carl Hanser Verlag, 2003.

Evans, P., and Wurster, T. S. Blown to Bits: How the New Economics of Information Transforms Strategy, Boston: Harvard Business School Press, 1999.

Ferstl, O. K., and Sinz, E. J. Grundlagen der Wirtschaftsinformatik ( $4^{\text {th }}$ ed.), Munich: Oldenbourg, 2001.

Gesellschaft für Informatik. "Rahmenempfehlung für die Universitätsausbildung in Wirtschaftsinformatik," Informatik Spektrum (25:2), 2003, pp. 108-113.

Gorgone, J., Feinstein, D., Longenecker, H. E., Topi, H., Valacich, J. S., and Davis, G. B. "Undergraduate Information Systems Model Curriculum Update-IS 2002," in R. Ramsower and J. Windsor (eds.), Proceedings of the Eighth Americas Conference on Information Systems, Dallas, TX, 2002, pp. 808-815.

Gorgone, J., Gray, P., Feinstein, D., Kasper, G. M., Luftman, J. N., Stohr, E. A., Valacich, J. S., Wigand R. T. "Model Curriculum and Guidelines for Graduate Degree Programs in Information Systems," Communication of the Association for Information Systems (3:1), 2000 , pp. 1-51.

Heinrich L. J. Wirtschaftsinformatik-Einführung und Grundlegung ( $2^{\text {nd }}$ ed.), Munich: Oldenbourg, 2001. 
Helfert, M., and Duncan, H. "Business Informatics and Information Systems - Some Indications of Differences in Study Programs," in D. Wainwright (ed.), Proceedings of UKAIS Conference, Northumbria University, Newcastle upon Tyne, March 24, 2005.

Holling, C. S. "Resilience and Stability of Ecological Systems," Annual Review of Ecology and Systematics (4), 1973, pp. 1-23.

Mallak, L. A, "Putting Organizational Resilience to Work," Industrial Management (40:6), 1998, pp. 8-13.

Mertens, P. "Geschichte und ausgewählte Gegenwartsprobleme der Wirtschaftsinformatik," WiSt Wirtschaftswissenschaftliches Studium (24:4), 1998, pp. 170-175.

Scheer, A.-W. Wirtschaftsinformatik-Referenzmodelle für industrielle Geschäftsprozesse (Studienausgabe) ( $2^{\text {td }}$ ed.), Berlin: Springer, 1998.

Wissenschaftliche Kommission der Wirtschaftsinformatik. "Profil der Wirtschaftsinformatik," Wirtschaftsinformatik (35:1), 1994, pp. 80-81.

Winter, R. "An Executive MBA Program in Business Engineering: A Curriculum Focusing on Change," Journal of Information Technology Education (1:4), 2002, pp. 279-288.

\section{About the Authors}

Markus Helfert is a lecturer in Information Systems at the School of Computing, Dublin City University (Ireland). His research centers on information quality management and includes research areas such as data warehousing, healthcare information systems, supply chain management, and information system architectures. He is program chair for the European Master of Science in Business Informatics. Markus can be reached by e-mail at markus.helfert( computing.dcu.ie.

Howard Duncan is a lecturer at the School of Computing, Dublin City University (Ireland). His research interests are in business process management, software engineering, and project management. He teaches courses in business organization, application programming, and business process management. Howard can be reached by e-mail at howard@computing.dcu.ie. 


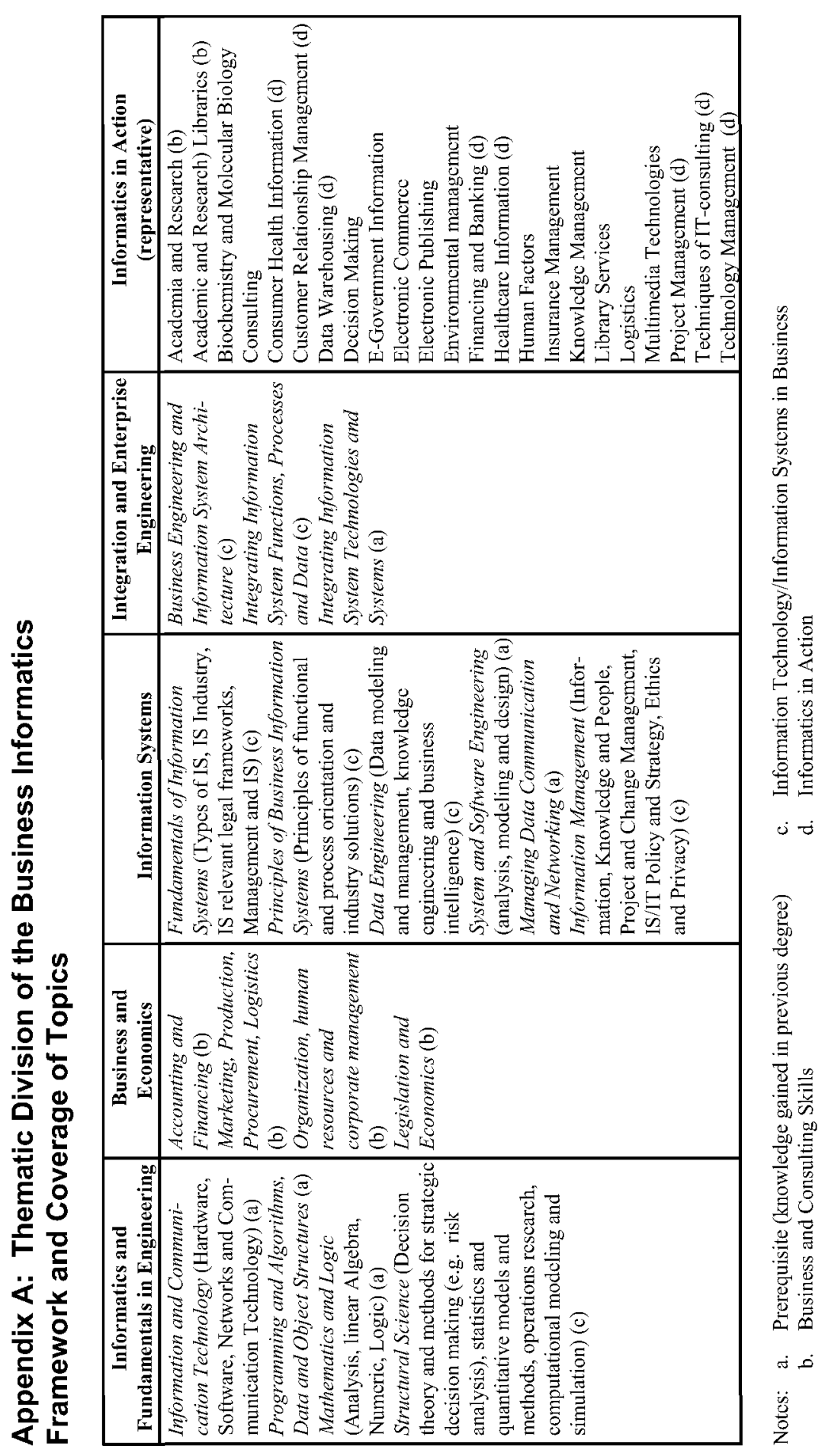






